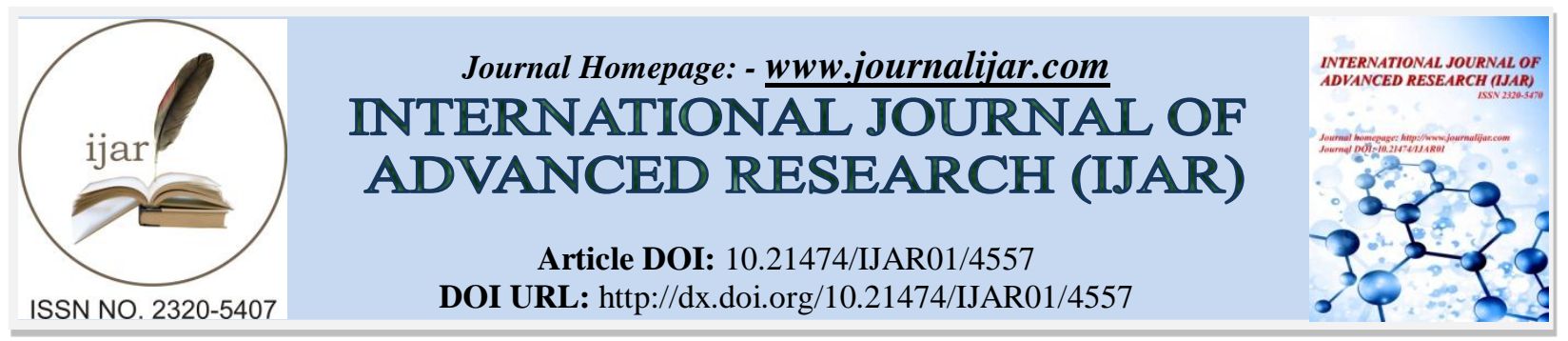

RESEARCH ARTICLE

\title{
A STUDY ON MUNICIPAL SOLID WASTE MANAGEMENT IN VISAKHAPATNAM CITY.
}

"Prem Kumar Dara ${ }^{1}$, T. Byragi Reddy ${ }^{2}$ and Ketema Tilahun Gelaye ${ }^{1}$.

1. Associate Professor, Gambella University, Ethiopia.

2. Professor, Andhra University, India.

3. Assistant Professor, Gambella University, Ethiopia.

\section{Manuscript Info}

(...........................

Manuscript History

Received: 21 April 2017

Final Accepted: 23 May 2017

Published: June 2017

Key words:-

Municipal Solid Waste, Greater

Visakhapatnam Municipal Corporation,

Municipal Solid Waste (Management \&

Handling) Rules2000.

\section{Abstract}

Municipal solid waste management is a problem that is experienced by all counties in the world. Because of its nature, it has remained one of the major environmental problems man continues to face. Municipal solid waste management is considered as one of the most serious environmental and social problems challenging municipal authorities in all major cities in India. Greater Visakhapatnam Municipal Corporation (GVMC) is facing lot of hardship in day to day management and maintenance of solid waste management. Therefore the present study was taken to find out the problems and prospects of Municipal solid waste in Visakhapatnam city. A detailed investigation was made regarding the methods of practices associated with sources, quantity generated, collection, transportation, storage, treatment and disposal of Municipal solid waste in Visakhapatnam city. The data concerning to SWM in Visakhapatnam was obtained through questionnaire, individual field visit, interacting with people and authentic record of municipal corporation. Photographic evidences were also made about generation, storage, collection, transportation, treatment and disposal of MSW. The study reveals the issues to be addressed for a more effective and efficient solid waste management practices in Visakhapatnam city as per Municipal Solid Waste (Management \& Handling) Rules 2000.

Copy Right, IJAR, 2017,. All rights reserved.

\section{Introduction:-}

Problems with the disposal of wastes can be traced from the time when humans first began to congregate in tribes, villages and communities and the accumulation of wastes became a consequence of life (George Tchobanoglous, 1993). Improper disposal leads to the breeding of rats, with their attendant fleas carrying the germs of disease causing plague. Lack of planning and management of solid waste led to epidemic of plague, the Black Death that killed half of the Europeans in the $14^{\text {th }}$ century and caused many subsequent epidemics and high death tolls.

Solid waste management is a integral part of urban and environmental management of each city with more than $65 \%$ of India's 250 million population living in class I town (population over 0.1 million) and 23 cities getting distinction of being metropolises (population over 1million) (Asnani et al; 1992, Bhide and Sudarshan, 1976) Municipal solid waste management, like most of other infrastructural services has come under great stress, consider low priority areas, solid waste management was never taken up seriously either by public or by concerned agency or authorities 
and now the piled up waste is threatening our heath, environment and well being (Chouhan and Reddy 1996, Mazumdar 1994).

Visakhapatnam is the second biggest city in undivided Andhra Pradesh after Hyderabad. Once a small fishing village has evolved into major port city in south India over the decades and considered as the fastest growing city in India. The total area of the city is 540 sq.km (GVMV, 2012) and with Greater Visakhapatnam Municipal corporation jurisdiction of 111 sq.km with a growing population of more than 30.82 lakhs. The city is the biggest economic hub with both public and private sector undertaking like Visakhapatnam Steel Plant, Visakhapatnam Port, National Thermal Power Corporation, Hindustan Petroleum Corporation, Hindustan Zinc, Hindustan Shipyard, Bharat heavy Plates and Vessels and any more private companies are located in and around the city generating huge amounts of waste. The Public Health and Sanitation Department of GVMC is responsible for collection, transportation and disposal of solid waste generated in Visakhapatnam City. The present study is carried out in the Greater Visakhapatnam Municipal Corporation area in the year 2012 to understand the solid waste management scenario in GVMC area.

\section{Materials and Methods:-}

The solid waste from the different sector of society was collected, mixed and one $\mathrm{Kg}$ sample was prepared by using quartering method. The waste was then characterized and the percentage of each constituent was calculated .Secondary data regarding solid waste generation, collection system and disposal methods were collected from GVMC.

\section{Results and Discussions:-}

Salient features of Solid waste management in GVMC:-

The Public Health and Sanitation Department of GVMC is responsible for collection, transportation and disposal of solid waste generated in Visakhapatnam City. For operational purposes the entire area of the corporation is divided into 6 zones comprising 72 wards. Sanitary Supervisors heads each of the zones and the sanitary inspector heads each of the wards. While the primary collection in the city is carried out through tricycles and 6 container wheel barrows and push carts the secondary collection would be done through dumper bins and open collection points shown below in table 1 .

Table 1:- Salient Features of Solid Waste Management in GVMC

\begin{tabular}{|c|c|}
\hline Item & Details \\
\hline Frequency of waste collection & Daily \\
\hline Number of Dustbins-dumper bins & 598 \\
\hline Average spacing of dumper bins, $\mathrm{km}$ & 0.64 (without considering single lane and internal streets) \\
& 4.75 (Considering single lane and internal streets) \\
\hline Number of sanitary workers & 3,772 \\
\hline Number of secondary collection points & 700 \\
\hline
\end{tabular}

Source Greater Visakhapatnam Municipal Corporation

According to GVMC at present the quantity of waste generated is around 737 tons per day with an average per capital solid waste generated by the city works out to around $489 \mathrm{gm} / \mathrm{capital} / \mathrm{day}$. The major sources of solid waste generating units are given in table 2 .

Table 2:- Sources of Municipal Solid Waste in GVMC.

\begin{tabular}{|c|c|c|}
\hline SN & Source & No. of Units \\
\hline 1 & Domestic Households & 365875 \\
\hline 2 & Commercial establishments & 60000 \\
\hline 3 & Lodges & 720 \\
\hline 4 & Star Hotels & 222 \\
\hline 5 & Hotels & 36 \\
\hline 6 & Restaurants & 36 \\
\hline 7 & Dhabas & 35 \\
\hline 8 & Markets (Large and Medium) & 89 \\
\hline 9 & Temples (Incl. small \& Big) & \\
\hline
\end{tabular}




\begin{tabular}{|c|c|c|}
\hline 10 & Hospitals & 16 \\
\hline 11 & Function Halls & 120 \\
\hline 12 & Cinema Halls & 33 \\
\hline 13 & Parks & 30 \\
\hline 14 & Schools & 110 \\
\hline 15 & Colleges / Universities & 71 \\
\hline 16 & Chicken Stalls & 267 \\
\hline 17 & Mutton Stalls & 58 \\
\hline 18 & Fish stalls & 5 \\
\hline 19 & Beef stalls & 2825 \\
\hline 20 & Road length in Kms & 3533 \\
\hline 21 & Drain length in Kms & \\
\hline
\end{tabular}

Source Greater Visakhapatnam Municipal Corporation

The city has various government hospitals, private hospitals, nursing homes and clinics .GVMC has contracted private agency that has set up a Biomedical Waste Processing Facility (BWPF) on NH5 near Madhurawada .The infectious waste from hospitals are collected by M/s.Maridi Eco Industries Pvt. Ltd agency at cost and being treated .The industrials waste from small unit get mixed in the municipal stream while the larger industries manage their own waste

\section{Solid waste Management system of GVMC:-}

At present around 598 dumper bins and 705 open secondary collection points spread across various parts of the city and 3772 sanitary workers manage to collect solid waste from various parts of the city. The existing solid waste management system in Visakhapatnam is shown in Fig 1.

Fig. 1:- Solid Waste management System in Visakhapatnam City.

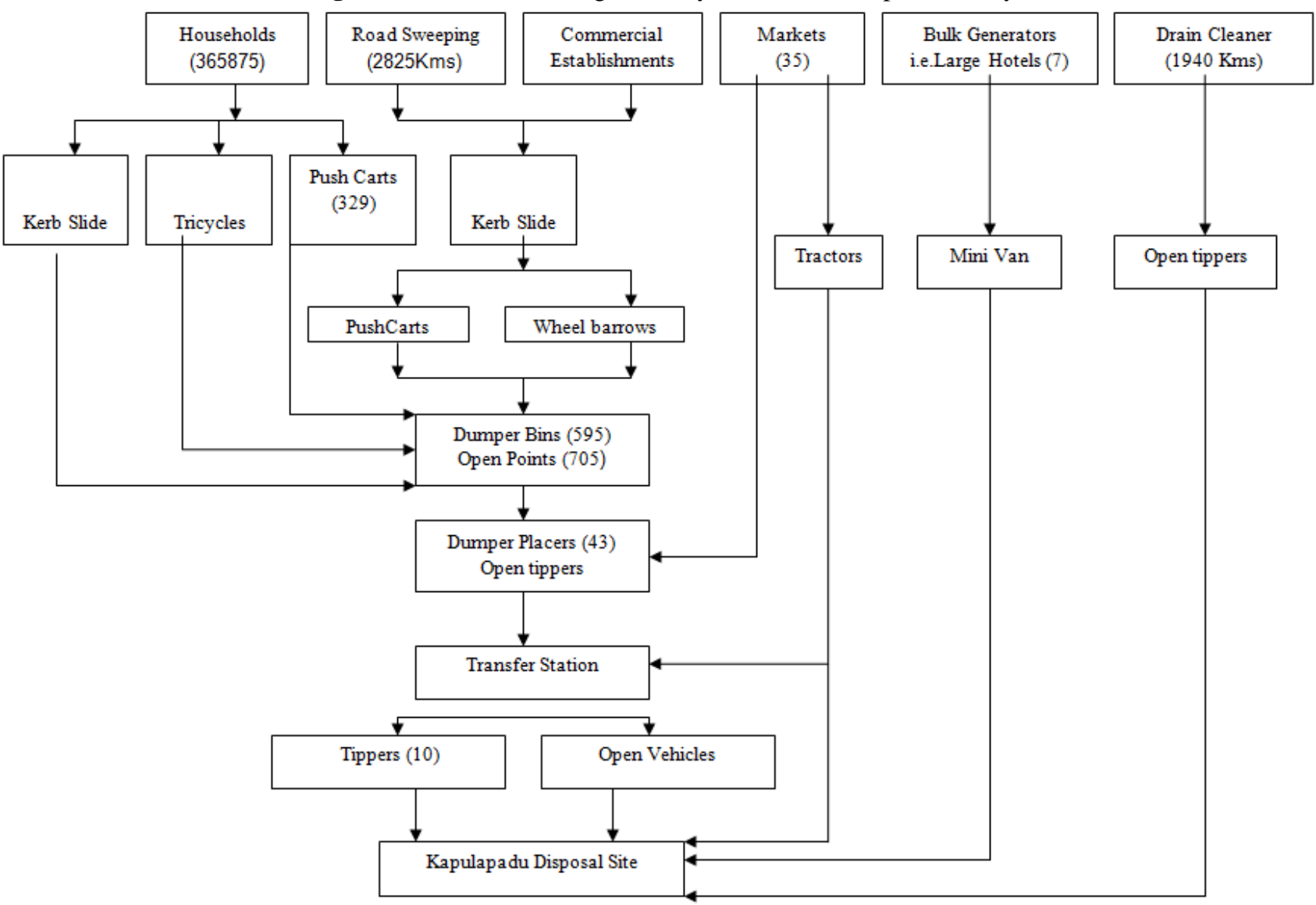




\section{Collection and Transportation:-}

The collection and transportation of solid waste in Visakhapatnam is done in two shifts. That first shift starts at 6 AM in the morning, the conservancy workers sweep the streets, clean he drains and collect the waste from small open points and transport the waste by 6 container wheel barrows or push cars or tricycles to nearest dumper bins or secondary open collection points. The waste from dumper bins and secondary open collection points is being transported to transfer stations by dumper placers or tippers or tractors than from transfer station the waste is being collected and transported to the disposal site by 20 tonners and open trucks. The entire municipal corporation is divided into 6 zones comprising 72 wards. Each zone is managed by Sanitary Supervisor and each ward is managed by Sanitary Inspector and is maintained by 3772 conservancy staff. Details of the Solid waste staff (Public Health Department) are given in table 3.

Table 3:- Details of the Solid waste staff (Public Health Department)

\begin{tabular}{|c|c|}
\hline Staff & Number \\
\hline Chief Medical Officer (Health) & 1 \\
\hline Assistant Medical Officer (Health) & 6 \\
\hline Sanitary Supervisors & 6 \\
\hline Sanitary Inspector & 51 \\
\hline Health Assistants & 21 \\
\hline Sanitary Masteries & 55 \\
\hline Sanitary workers & 3772 \\
\hline
\end{tabular}

Source: Greater Visakhapatnam Municipal Corporation

\section{Transfer Station:-}

There is one transfer station located at town road for transfer of waste from dumper placers and trucks to big tippers of 20 ton capacity. In this transfer station waste is weighed at the weigh bridge at the entrance, a record is being maintained for in time and out time, weight of the solid waste disposing in to the transfer station and vehicle number. The 20 ton capacity tippers transport the waste to disposal site at Kapulapada which is $25 \mathrm{Kms}$ away from city.

\section{Transportation:-}

The vehicles involved in the solid waste transportation in GVMC include dumper placers, tractors, mini vans, tippers and open trucks. Dumper Placers perform on average 12 trips per day from transfer station to dumping site. The tractors and dumpers carrying waste are not covered or partially covered during the journey and waste tends to spill on the roads. Most often workers are not provided with protective hand gloves and shoes so they are directly expose to the waste. Protective measures are necessary to avoid contracting skin allergies and respiratory diseases. The loading and unloading of waste is done through mechanical system reducing direct contact of worker with the wastes. The vehicles used for collection in GVMC are given in table 4.

Table 4:- Vehicles used for Collection for GVMC.

\begin{tabular}{|c|c|c|}
\hline SN & Vehicle & Number \\
\hline 1 & Dumper Placers & 43 \\
\hline 2 & Vans & 13 \\
\hline 3 & Big tippers & 10 \\
\hline 4 & Mini tippers & 2 \\
\hline 5 & Tractors & 1 \\
\hline 6 & Dead body van & 1 \\
\hline 7 & Tricycles & 532 \\
\hline 8 & Push carts & 329 \\
\hline 9 & Wheel barrows (6tube) & 218 \\
\hline
\end{tabular}

\section{Processing and Disposal:-}

GVMC is not practicing any scientific processing in disposal of solid waste. The solid waste collected is being transported to the Kapulapadu disposal site where it is disposed indiscriminately. Presently GVMC is practicing open crude indiscriminate disposal of solid waste. The disposal site falls under Kapulapada Village of BhimilipatnamMandal and is located on the northern side of the Visakhapatnam city on NH5 with approximate site 
area of 80 acres. The approach road to the site is very narrow passing wild stream which carries water only during rainy period. The site is $25 \mathrm{kms}$ from Airport and $0.5 \mathrm{~km}$ from the NH-5. Biomedical waste treatment plant is run by a private agency M/s. Maridi Eco Industries Pvt.Ltd in 5 acres.

The site is steeply sloping from North to South and East to West direction with a contour variation from 60.00meters to 30.00 meters.

\section{Characteristics and Composition of Solid Waste:-}

The quantity and characteristics of solid waste vary from place to place .factors that influence the quantity and composition are the average income level, the sources, the population, social behavior, climate, industrial production and the market for waste materials. The study showed the waste generated in Visakhapatnam is heterogeneous in nature. The major constitutions of solid waste generated in Visakhapatnam are organic waste. The physical characteristics of the city waste, as a percentage by weight is given in Table 5 .

Table 5:- Physical Analysis of Solid Waste in Visakhapatnam.

\begin{tabular}{|c|c|c|}
\hline SN & Components & \% Composition by weight \\
\hline 1 & Paper & $4 \%$ \\
\hline 2 & Glass & $<1 \%$ \\
\hline 3 & Plastics/cans & $3.5 \%$ \\
\hline 4 & Bio-degradable matter & $40-45 \%$ \\
\hline 5 & Inert waste/silt/debris & $45-50 \%$ \\
\hline 6 & Others & $2-3 \%$ \\
\hline & Total & 100 \\
\hline
\end{tabular}

\section{Conclusions:-}

Solid Waste management practices in Visakhapatnam appears to be inadequate and need improvements. Segregation of waste at source is one of the important recommendations of MoEF in its guidelines on solid waste management, but it is absent in Visakhapatnam. A system approach needs to be adopted for optimizing the entire operation of SWM encompassing segregation at source, timely and proper collection, transportation routes and types of vehicles and development and proper operation of sanitary landfill site. More emphasis should be laid on scientific waste processing and disposal strategies for the city including effective utilization of the organic waste and recyclables and the development of land fill facility catering to the next 25-30 years period in line with the Municipal Solid Waste (Handling \&Management) Rules 2000.

\section{References:-}

1. Asnani, P.U , SR Shukla and PS Rajvanshi (1992) Solid waste management all India.

2. Bhide A.D and Sudarshan (1976) Solid waste management in developing countries.

3. Chouhan B.M and B.K Reddy (1996) Bio-energy scenario in India.IREDA News. 7(1):20-27

4. Dhande A.D. Ingle sopan T, Attarde Sanjay B and WaghNileshD : (2005), Ecofriendly approach of urban solid waste management - A Case Study of Jalgaon city, Maharastra, J. Envron. Biols 26 (4): 747-752.

5. G.P. Shivashankara, H.B Rekha (2005) Solid waste management in suburban areas of Bangalore. Nature Environment and Pollution Technology 4(4): 495-500.

6. George Techobanoglous, Hilary Theisen, and Samuel Vigil (1993), Integrated Solid Waste, GIS development .net/Application/Urban/overview/urban 0025.html.

7. Greater Visakhapatnam Municipal Corporation, www.GVMC.Org.

8. Indian standards Institution IS - 10158 (1992).Method of Analysis of solid waste.

9. Jha MK, Sondhi OAK and Pansare M (2003) Solid waste Management - A case study IJEP, 23 (11): 1153 1160

10. Macwan J.E.M, Jay Shukla, Peritapatel and Bhumika Shah (2003) Metropolitan Domestic Solid waste Generation Analysis in Indian context” Journal of Indian Association Env.al Management Vol. 30:158-161.

11. Malvia R, Choudhary R and BudhiaDharam (2002) Study on solid waste assessment and management. Indore city. IJEP 22(8): 841-846.

12. Mazumdar,N.B (1994) Municipal solid waste management the Indian perspectives.Environment Monitor, 12(2): 257-269. 
13. Renjini RL and Prakasam V.R, (2005) An evaluation of Municipal solid waste management in Tripunithura Municipality of Kerala ,IJEP; 25 (7) :652-656.

14. Shannigrahi A.S. Chatterjee N and Olamiya M.S (1997) Physicochemical characteristics of Municipal solid waste in to mega city, Indian journal of Env .al Portection Vol. 17: 527 - 529.

15. Shekdar, A.V. (1999) Municipal solid waste management. The Italian Perspective Journal of MEM, 27: 100108.

16. Tambekar D.H. and Kale S.A (2005) A study on physicochemical characteristics of Municipal solid waste of Amravati city, Maharashtra, Nature Env. And Pollution Tech. Vol. 4, No. 3:459 - 462

17. Tehabanoglous $\mathrm{G}$ et al, Theisen $\mathrm{H}$ and Eliassen R, (1993) Solid waste Engineering principle and management , MG-Graw Hill, New York.

18. Yishu Chiu, Joan Eryrter and George W. Gipe, (1976) Solid Waste Generation. Rates of a University Community. Journal of Env.al EnggDivison ASCE vol 102 -, PP: 340 - 345. 